\title{
CHALLENGES ENCOUNTERED AND STRATEGIES EMPLOYED IN MANAGING STUDENTS' BEHAVIOR OF JUNIOR HIGH SCHOOL TEACHERS OF A PRIVATE SCHOOL IN QUEZON PROVINCE
}

\section{GARRY C. LINGON, MAED}

\section{ABSTRACT}

This study determined and analyzed the challenges encountered and strategies employed by Junior High School Teachers in managing the students' behavior, who were the respondents of the study, in a private school in Quezon Province that gave way to the creation of a Teachers' Guidebook on Managing the Students' Behavior as an output. The descriptive-evaluative method of research was used in the study together with the Weighted Arithmetic Mean (WAM) as the statistical tool. Further, a validated researcher-made instrument was used to gather the needed data in the study.

Based on the findings of the study, under the code of conduct related to discipline, the respondents revealed the challenges encountered in managing students' behavior. The statements that got the highest WAM rating were (1) Failure of students to wear their uniform in official activities held inside or outside the school; (2) Students forget their ID at Home; and, (3) Failure of the students to accomplish their excuse slip form.

In addition, the code of conduct related to decorum, the following are some of the challenges encountered by the respondents: (1) Students do not maintain silence when no teacher is around; (2) Students fight with their classmates when they lose their temper; (3) Students disrespect the sacredness of the chapel by uttering nasty words inside the place; (4) Students ignore teacher's instructions and do some foolishness with their friends; (5) Students disobey the rules and regulations of the school; (6) Students are buying foods even though it is not a break time; (7) Students fail to maintain silence inside the library; (8) Students do not observe silence while buying in the cafeteria; (9) Students do not participate in the mass instead they talk to their classmate; and, (10) Students talk with their classmate while flag ceremony is on-going.

The findings of the study revealed that the orientation of the students was needed to familiarize the students on the rules and regulations implemented in the school and to consistently impose discipline.

The following recommendations are made by the researcher: The students should understand fully the importance of following the school's rules and regulations by taking seriously the identified school policy on the code of conduct. The teachers should conduct an annual orientation/re-orientation program that emphasizes the findings of this research, and seriously consider more effective strategies to overcome problems on code of conduct and use the output of this study. The school administrators should issue a school memorandum requiring all teachers and school staff to strictly implement the school policies. The future researchers should make a study on the assessment of the quality of the school policies implemented in the private schools in Quezon Province.

Keywords: challenges, management of student behavior, strategies, teachers' guidebook on managing students' behavior 


\section{INTRODUCTION}

Nooruddin and Baig (2014) described student behavior management as one of the contemporary issues frequently faced by the school community. Behavioral problems such as bullying, violence in school and other major and minor misconduct issues lead to poor environment and a sense of fear and frustration within the school community.

With aforementioned thought, it is important to manage the students' behavior to attain the DepEd's mission statement that states "students learn in a child-friendly, gender sensitive, safe, and motivating environment (retrieved in DepEd website, 2018). This kind of learning environment is the main concern of school heads in order to attain the said mission for the holistic development of the students. In connection with DepEd Order No. 1, s. 2003 also known Promulgating the Implementing Rules and Regulations (IRR) of Republic Act No. 9155 otherwise known as the Governance of Basic Education Act of 2001, the environment is a vital part of the teaching and learning process and that the school head shall have authority, accountability, and responsibility for creating this kind of environment in the school.

It is further supported by DepEd Order No. 44, s. 2005 also known as Declaration of Schools as Zones of Peace which emphasizes that the school is a zone of peace that should provide a special environment for the formal, physical, mental, emotional, and moral growth of the young. The laws for the school environment make up a better school climate for the learners. However, in order to motivate them to learn and stay in school the teachers should take charge to ensure the quality of school management specifically in managing students' behavior which is implicitly stated in DepEd Order No. 92, s. 1992 also known as the Revised Manual of Regulations of Private Schools (8th Edition). It is also mentioned that every school shall maintain discipline inside the school campus as well as outside the school premises.

In the light of this DepEd order, the teachers should be careful in dealing with the misbehavior of the students. Also, this DepEd order advocates positive discipline in developing the sense of responsibility and self-discipline among students as well as to every educational institution which endeavors to create an atmosphere conducive to learning. Thus, students should observe the rules and regulations prescribed by the school.

However, this cannot be attained if the students do not follow the rules and regulations of the school. The problem will arise due to the number of violations committed by students. According to the Student Supreme Council (SSC) record of the academic year 2017-2018 in one of the private schools in Sariaya, the students committed a total of 775 violations. Most of the committed violations are the following: not following the prescribed uniform and grooming, tardiness, bringing of cellphone without permit, and not bringing their handbook and ID.

Likewise, another example of student misbehaviors are based on the records of Office of Guidance Counselor for A.Y. 2018-2019 of a private school in Quezon Province, the violations/offenses committed by the students as regards their attitudes and values are bullying, fighting, vandalism, falsification of signature in the excuse slips, posting of rants on social media using vulgar words, extortion of money from the lower grade levels, abusive behavior/discourtesy towards school personnel, repeated name teasing/name calling, and public display of affection. The violators are subjected to disciplinary actions depending on the gravity of the offense.

The aforementioned issues prompted the researcher to come up with this research in order to help resolve the problems of the students and to assist the teachers to address the challenges met in school. The researcher developed a Teachers' Guidebook on Managing Students' Behavior for 
Junior High School teachers. This study showcased the strategies employed by the teachers in managing student behavior.

\section{Statement of the Problem}

This study aimed to identify the challenges encountered and strategies employed in managing students' behavior by Junior High School teachers in a private school in Quezon Province.

Specifically, the study sought to answer the following questions:

1. What are the challenges encountered by the Junior High School teachers of a private school in Quezon Province in managing student behavior, in terms of:

1.1. Code of conduct related to discipline; and

1.2. Code of conduct related to decorum?

2. What are the strategies used by the Junior High School Teachers in addressing the challenges met in managing student behavior, in terms of:

2.1. Code of conduct related to discipline; and

2.2. Code of conduct related to decorum?

3. Based on the findings of the study, what Teachers' Guidebook on managing student's behavior can be offered to the Junior High School teachers?

\section{Theoretical Framework}

This research was anchored on the theory of B.F. Skinner; changes in behavior are a result of individuals' responses to events or stimuli that occur in their environment. When a stimulusresponse (S-R) pattern is rewarded, the individual is conditioned to respond similarly in the future (Huston University Online, 2019).

The idea of Skinner is about the creation of the learning environment that is conducive for learning. The students responsed to their environment especially to the rules and regulations implemented in the school. An institution conducts an orientation for the students about the rules and regulations in terms of code of conduct related to discipline and code of conduct related to decorum. The purpose of the orientation is to give the students a greater awareness about the rules and regulations implemented in the school. However, the orientation become successful if these rules and regulations are firmly implemented in every educational institution. Thus, the students should be responsible for following these rules with the guidance of their teachers.

In connection with the theory of Skinner, Ford (1994) developed the "Responsible Thinking Process" also known as RTP which states that educators need to develop a sense of responsibility of the students for their own lives and to respect the lives of everyone around them. It creates mutual respect by teaching students how to think through what they are doing in relation to the rules of wherever they are. This gives students personal accountability for their actions. The 
key component of this classroom discipline process is its focus on how students can achieve their goals without getting in the way of others who are trying to do the same thing (Weebly, 2019).

From the thoughts of Ford, there is a need to inculcate in the students that they are accountable for their action. The students should respect the rules and regulations that are really important to develop in them the sense of responsibility for their action in order to maintain the peace and order in the school.

Therefore, every educational institution should impose discipline to the students. In that case, if the students break the rules there are always consequences for their action. For that reason, imposing rules and regulations is one of the strategies could that be enforced to get the positive behavior of the students.

The aforesaid theories were the benchmarks of the researcher in the development of the research output entitled Teacher's Guidebook on Managing Student Behavior. This output showcases strategies that could help the respondents to address the challenges in managing the behavior of the students in terms of the code of conduct related to discipline and code of conduct related to decorum.

The code of conduct related to discipline focuses on the following: wearing of the uniform, school ID, and attendance (absences, tardiness, and cutting classes). Further, the code of conduct related to decorum focuses on the following: silence, respect and friendliness, in the chapel, in the classroom, in the campus, in the library, in the cafeteria, attendance at mass, during the flag ceremony, use of the student facilities, school's sustainable waste management program, offcampus activity, use of cellphone and other e-gadgets, boy and girl relationship, and safety measure.

The researcher determined the challenges encountered and strategies in managing students' behavior employed by the Junior High School teachers in a private school in Quezon Province. The researcher's intention is to help them address the misbehavior of the students, thus, better reinforcement of rules and regulation in the code of conduct related to discipline and code of conduct related to the decorum of the school might produce disciplined students inside and even outside the school campus.

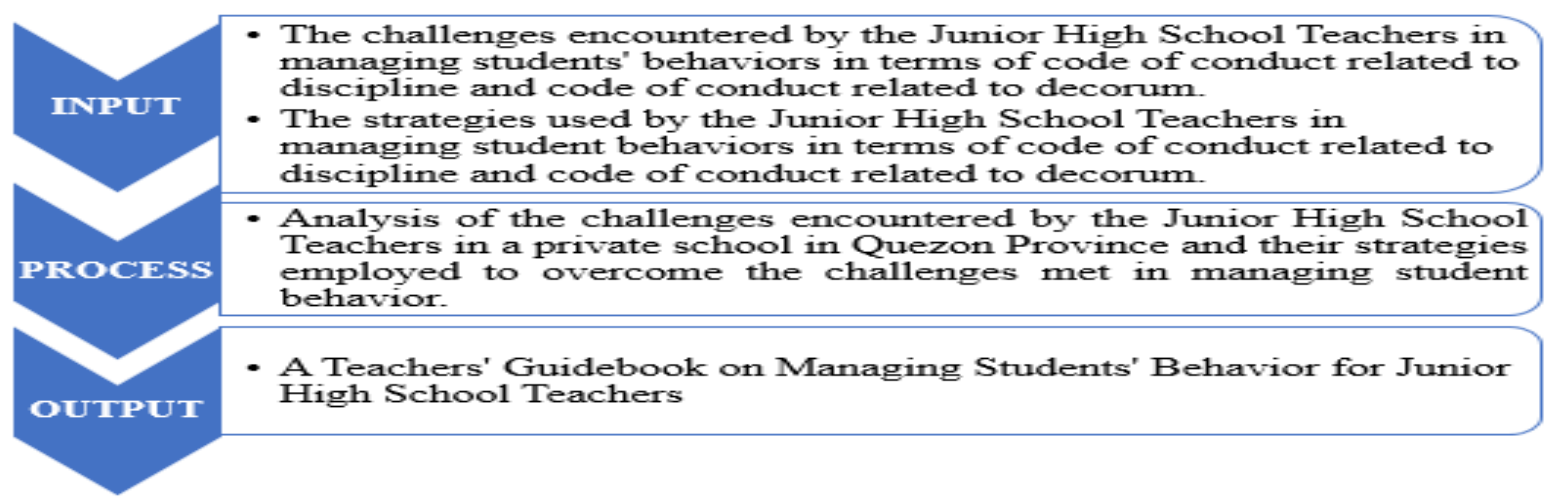

Figure 1. Theoretical paradigm showing the challenges encountered and strategies in managing student behavior employed by Junior High School teachers in a private school in Quezon Province. 


\section{Theoretical Paradigm}

Figure 1 shows the theoretical paradigm followed by the researcher. This is composed of the Input-Process-Output model.

The input of this research were the challenges encountered by the Junior High School Teachers in managing the students' behavior in terms of the code of conduct related to discipline and code of conduct related to decorum. It also included the strategies employed by Junior High School teachers in addressing the challenges in managing the students' behavior based on the findings of the study.

Then, the process of this research included the analysis of the findings on the challenges encountered and strategies employed of Junior High School teachers in managing the students' behavior in terms of the code of conduct related to discipline and code of conduct related to decorum.

The results were the bases for the development of Teachers' Guidebook with tips on managing and dealing with the students' behavior. The output was intended to help the Junior High School teachers in a private school in Quezon Province who face challenges in managing the behavior of the students. It is a way of addressing and resolving the problem of students' misbehavior.

\section{Scope and Limitation}

The purpose of the study was to determine the challenges encountered and strategies employed by the Junior High School teachers in managing the challenges in students' behavior in terms of the code of conduct related to discipline and code of conduct related to decorum. Based from the result of the study, the researcher developed Teachers' Guidebook about managing students' behavior.

As the limitation of the study, some of the variables considered by the researcher under the code of conduct related to decorum were in the chapel, during the flag ceremony, and boy-girl relationship which are based on the Student Handbook of Sacred Heart College (2011) these variables have no clear rules and regulations written in the Student's Success Handbook of the research locale. Due to this, the three variables were considered and included in the content of the output.

The respondents of this study were thirty Junior High School teachers from a private school in Quezon Province. With regard the research instrument, a validated research-made questionnaire was utilized in gathering the data. To find out the result of the data gathered, statistical analysis was done through the use of WAM (Weighted Arithmetic Mean). The duration of the study was from July 7, 2018, to May 4, 2019.

\section{RESEARCH METHOLOGY}

\section{Research Design}

This study employed the descriptive-evaluative method of research since it basically described the condition of schools in terms of managing student behavior. Specifically, the main 
focus of the study was to identify the challenges encountered and strategies employed in managing the students' behavior by the Junior High School teachers in a private school in Quezon Province.

A Teachers' Guidebook on Managing the Students' Behavior as the output of the study was developed to enhance the strategies employed by the Junior High School teachers to manage the behavior of the students. In this output, the teachers are guided in managing the student behavior and were given tips on how to cope effectively with those challenges.

\section{Research Locale}

The study was conducted in an institution located at Poblacion 1 Rama St. Muntingbayan Sariaya, Quezon. This institution is one of the Catholic schools in Quezon Province. Based on the record of the Registrar's Office, supported by the Office of the Principal, the total number of enrollees in that institution for the A.Y. 2018-2019 is 1060. It is composed of one hundred seventyone (171) Grade School pupils, seven hundred ten (710) Junior High School students, and one hundred seventy-nine (179) Senior High School students.

The prominent program implemented in the school to address the students' misbehavior is peer counseling from Grade 7 to Grade 10 headed by trained Grade 12- HUMMS students who are supervised by the Guidance Advocate. The purpose of this program is to release the stresses or problems of the students through the help of Grade 12-HUMMS. It is a closed door program where the students and facilitators are the only persons inside the classroom to make it private and avoid inhibitions. The program is on its second year of implementation; based on the feedbacks of the students and teachers, a great improvement is seen among the behavior of the students. Despite of this effort, still a number of students are seen with negative behavior. This prompted the researcher to conduct this study to help the teachers having difficulty in management of students' behavior.

\section{Research Population}

The respondents of the study were the Junior High School teachers of a private school in Quezon Province who are teaching in the Junior High School Department and willing to participate in the study. Based on the records of the administrative secretary, the number of teachers who teach in the Junior High School Department was thirty (30) in total.

\section{Research Instrument}

The researcher used a researcher-made questionnaire which was divided into two parts. The first part elicited answers on the challenges encountered by the Junior High School Teachers in managing student behavior. There are fifteen (15) items for Code of Conduct Related to Discipline while seventy-six (76) items for Code of Conduct Related to Decorum for a total of ninety-one (91) items. The respondents checked the choices that correspond to their answers. The second part contained the strategies employed by Junior High School teachers in managing students' behavior. There are fifteen (15) items under the code of conduct related to discipline while seventy-five (75) items for Code of Conduct Related to Decorum for a total of seventy (70) items.

Before the researcher administered the questionnaire, the questionnaire underwent content validation by the three experts who were knowledgeable in the field. They were a principal, a 
guidance counselor, and a prefect of discipline. After this, the researcher revised the questionnaire based on the suggestions and recommendations of the validators with the assistance of the thesis adviser. Then, the researcher pilot tested the questionnaire in St. Joseph Academy of Sariaya, an institution which is similar to the chosen research locale, to establish the validity and reliability of the instrument. In line with this, the researcher asked ten teachers in Junior High School Department about their thoughts for the questionnaire. The researcher revised the questionnaire based on the feedback gathered after the pilot testing.

\section{Data Gathering Procedure}

In accomplishing this study, the following procedures were considered:

The researcher sought the approval of the principal in the research locale. After receiving the approval, a copy of the questionnaire was given to the respondents of the study which were the Junior High School Teachers. The questionnaires were personally handed by the researcher to the respondents. This is to provide assistance in any questions that they have in accomplishing the questionnaires, however, the researcher did not in any way influence the respondents.

The distribution of the questionnaires was done after the faculty meeting of the respondents. They were given ample time to accomplish the research instrument to ensure the reliability of data.

Afterwards, the questionnaire were personally retrieved by the researcher to tally and statistically treat the responses of the respondents.

\section{Statistical Treatment of Data}

The researcher used a standard statistical tool in order to come up with the result of this study. These statistical tool was Weighted Arithmetic Mean (WAM).

1. Weighted Arithmetic Mean- the researcher used WAM to measure the responses of the respondents in terms of challenges encountered and strategies employed by the Junior High School Teachers in managing the student behavior. This was categorized into two Code of Conduct Related to Discipline and Code of Conduct Related to Decorum.

The formula for the weighted arithmetic mean is shown:

$$
\mathrm{WAM}=\frac{\sum \mathrm{fw}}{\mathrm{n}}
$$

Where: $\mathrm{f}$ is the frequency

$\mathrm{w}$ is the weight

$\mathrm{n}$ is the number of responses

The researcher utilized Simplified Statistics for Beginner (SSB) a software licensed to Sacred Heart College, Lucena City to facilitate the computation of the numerical data gathered. Moreover, the researcher used the four-point Likert Scale and qualitative indices. 
Each item in the questionnaire was answered by the respondents by using a four-point Likert scale using the verbal indices below. The researcher utilized these indices to determine the challenges encountered and strategies employed in managing the students' behavior by the Junior High School Teachers in a private school in Sariaya, Quezon.

To qualify the computed data, the researcher made use of the verbal continuum shown in the next page:

Continuum

$3.26-4.00$

$2.51-3.25$

$1.76-2.50$

$1.00-1.75$
Qualitative Index

Always

Sometimes

Seldom

Never

Source: SHC Statistical Guide Revised Edition, 2018

\section{RESULT AND DISCUSSION}

\section{Ethical Approval}

Written informed consent was obtained from all participants. All procedures performed in the study involving human participants were in accordance with the ethical standards of the institution and/or the oral examination committee (the Ethics Review on Research with Human Subject the Junior High School Teachers). As response to the privacy of the respondents and research locale, the researcher did not indicate the name of the respondents and research locale all throughout of the research. Especially, all the consent form and other documents did not indicate in the study in order to protect the name of the institution and respondents.

Part I. The challenges encountered by the Junior High School Teachers of a Private School in Quezon Province in managing student behavior, in terms of:

\subsection{Code of Conduct Related to Discipline}

Wearing School Uniform

The challenges encountered by the respondents in terms of wearing of school uniform are: (1) failure of students to wear their uniform in official activities held inside or outside the school (WAM $=2.37$, Seldom), (2) Student wear indecent clothes instead of school uniform in coming to school for practices, meeting, or any school approved activities (WAM=2.23, Seldom), and Students do not wear their P.E. uniform during P.E. classes (WAM=2.23, Seldom).

Wearing of School ID

The challenges encountered by the respondents in terms of wearing of school ID are: (1) Student forget their ID at home (WAM=2.47, Seldom), (2) Student lost their ID due to negligence $\mathrm{WAM}=2.30$, Seldom), and Student do not present their ID upon entering the school campus (WAM= 2.17, Seldom). 
Attendance (Absences, Tardiness, and Cutting Classes)

The challenges encountered by the respondents in terms of attendance are: (1) Failure of the students to accomplish their excuse slip form (WAM=2.80, Sometimes) and (2) Students make absences without valid reason (WAM $=2.60$, Sometimes).

\subsection{Code of Conduct Related to Decorum}

\section{Silence}

The challenges encountered by the respondents in terms of silence are: (1) Students make unnecessary noise which tend to distract classes or school activities (WAM=2.87, Sometimes), (2) Students do not maintain silence when they have no teacher in the classroom (WAM=2.87, Sometimes), and (3) Students are noisy while passing along corridors, chapel, classroom, conference room, and other school offices (WAM=2.57, Sometimes).

\section{Respect and Friendliness}

The challenges encountered by the respondents in terms of respects and friendliness are: (1) Students fighting with their classmates when they lose their temper (WAM=2.80, Sometimes), (2) Students are not showing respect when talking to neighbor or elderly (WAM=2.6, Sometimes) and the students do not show respect in dealing with school administrators, teachers, and any school personnel (WAM=2.57, Sometimes).

\section{In the Chapel}

The challenges encountered by the respondents in the chapel are: (1) Students disrespect the sacredness of the chapel by uttering nasty words inside the place (WAM=2.33, Seldom), (2) Students visit the chapel not to pray but to talk with their friend (WAM=2.07, Seldom), and (3) Students are noisy inside the chapel (WAM=2.07, Seldom).

\section{In the Classroom}

The challenges encountered by the respondents in the classroom are: (1) Students ignore my instructions and do some foolishness with their friends (WAM=2.83, Sometimes), (2) Student play inside the classroom which lead to destruction of school properties (WAM= 2.70, Sometimes), and (3) Students roam around the classroom while the discussion is still on-going (WAM= 2.67, Sometimes).

\section{In the Campus}

The challenges encountered by the respondents in the chapel are: (1) Students disobey the rules and regulations of the school (WAM=2.73, Sometimes), (2) Students are buy foods even though it is not a break time (WAM=2.73, Sometimes), and (3) Students are stay in the corridors and stairways while classes are going on (WAM=2.60, Sometimes).

\section{In the Library}

The challenges encountered by the respondents in the library are: (1) Students fail to maintain silence inside the library (WAM=2.50, Seldom) and (2) Students fails to arrange their chairs after using them (WAM=2.27, Seldom). 


\section{In the Cafeteria}

The challenges encountered by the respondents in the cafeteria are: (1) Students do not observe silence while buying in the cafeteria (WAM=2.67, Sometimes), (2) Students leave their tables unclean (WAM=2.67, Sometimes), (3) Students do not fall in line in the cafeteria to buy or purchase food (WAM= 2.53, Sometimes), and (4) Students do not throw their trash in the designated containers/receptacles/bins (WAM=2.50, Seldom).

\section{Attendance at Mass}

The challenges encountered by the respondents in terms of attendance at mass are: (1) Students do not participate in the mass instead they talk to their classmate (WAM= 2.70, Sometimes), (2) Students do not attend mass every Sunday and Holy Days of Obligation (WAM=2.57, Sometimes); and, Students forge the signature of the teacher or any authorized person $(\mathrm{WAM}=2.5$, Seldom $)$.

\section{During the Flag Ceremony}

The challenges encountered by the respondents during flag ceremony are: (1) Students talk with their classmate while flag ceremony is on-going (WAM=2.9, Sometimes), (2) Students do not participate in the flag ceremony e.g. singing the Philippine National Anthem, Calabazon March, and Assisian Hymn (WAM=2.8, Sometimes), and (3) Students do not listen to the announcement after the flag ceremony (WAM=2.87, Sometimes).

\section{Use of the School Facilities}

The challenges encountered by the respondents in terms of use of the school facilities are: (1) Students do not follow the rules and regulations in the classroom (WAM=2.8, Sometimes), (2) Student failure to clean the board properly (WAM=2.77, Sometimes), (3) Students do not follow the rules and regulations in the covered court (WAM=2.67, Sometimes), (4) Students do not turn off the lights and electric fans (WAM=2.63, Sometimes), and (5) Students do not follow the rules and regulations in the library (WAM $=2.57$, Sometimes)

\section{School's Sustainable Waste Management Program}

The challenges encountered by the respondents in terms of school's sustainable waste management program are: (1) Students do not put plastic bottles in the designated trash can (WAM= 2.90, Sometimes) and (2) Students ignore the proper use of the trash can/bin e.g. setting a part of biodegradable and non- biodegradable (WAM=2.83, Sometimes).

\section{Off-campus Activity}

The challenges encountered by the respondents in terms of off-campus activity are: (1) Students get involved in any trouble while the activity is on-going (WAM=2.53, Sometimes) and (2) Students doing annoying things that will distract to other participants of the activity (WAM=2.53, Sometimes).

\section{Use of Cellphone and Other E-gadgets}

The challenges encountered by the respondents in terms of use of cellphone and other egadgets are: (1) Student bring cellphone or any gadgets without a permit (WAM= 2.53, Sometimes), (2) Students do not surrender their cellphone to their class adviser (2.30, Seldom), 
and (3) Students secretly take pictures/videos of their classmates or their teachers though they know it is prohibited (WAM=2.10, Seldom).

\section{Boy and Girl Relationship}

The challenges encountered by the respondents in terms of boy and girl relationship is students public display of affection to their boyfriend/girlfriend in their classroom or any places in the school (WAM=2.33, Seldom).

\section{Safety Measure}

The challenges encountered by the respondents in terms of safety measure is students do not participate in the earthquake or any drill (WAM=2.27, Seldom).

Part II. The strategies used by the Junior High School Teachers of a Private School in Quezon in overcoming the challenges met in managing student behavior, in terms of:

\subsection{Code of Conduct Related to Discipline}

\section{Wearing of the School Uniform}

The strategies employed by the respondents in overcoming the challenges they encountered in terms of wearing of the school uniform are: (1) I accompany the erring student to the guidance counselor or prefect of discipline to address the violation (WAM=3.10, Sometimes) and (2) I suggest to the security officer to check the students who repeatedly violate the proper wearing of school uniform (WAM=2.23, Seldom).

\section{School ID}

The strategies employed by the respondents in overcoming the challenges they encountered in terms of school ID are: (1) I confiscate the ID of the students who tamper or lend their ID's (WAM=3.10, Sometimes) and (2) I give warning to the students who constantly violate the rules and regulations on wearing their ID's (WAM=2.53, Sometimes).

\section{Attendance}

The strategies employed by the respondents in overcoming the challenges they encountered in terms of attendance is conducting a home visitation to relay the no. of day of absences and the reason behind the absences of the students (WAM=3.03, Sometimes).

\subsection{Code of Conduct Related to Decorum}

\section{Silence}

The strategies employed by the respondents in overcoming the challenges they encountered in terms of silence by never allowing the students go to inside the classroom if the students are noisy (WAM=3.17, Sometimes).

\section{Respect and Friendliness}

The strategies employed by the respondents in overcoming the challenges they encountered in terms of respect and friendliness by calling the attention of the misbehaving student for conference (WAM= 3.63, Always). 


\section{In the Chapel}

The strategies employed by the respondents in overcoming the challenges they encountered in the chapel is letting the students clean the chapel (WAM=3.3, Always).

\section{In the Classroom}

The strategies employed by the respondents in overcoming the challenges they encountered in the classroom by referring the student who misbehaves to the guidance counselor or prefect of discipline (WAM= 3.2, Sometimes).

\section{In the Campus}

The strategies employed by the respondents in overcoming the challenges they encountered in the campus by discouraging the students to take their break during classes (WAM=3.23, Sometimes).

\section{In the Library}

The strategies employed by the respondents in overcoming the challenges they encountered in the library are: (1) I impose fines to the students who do not follow the due date of borrowed books in the library (WAM=2.87, Sometimes), (2) I use signage's reminding the students of their responsibility inside the library (WAM=3.13, Sometimes), and (3) I assure close supervision of the students when the students are inside the library (WAM=3.20, Sometimes).

\section{In the Cafeteria}

The strategies employed by the respondents in overcoming the challenges they encountered in the cafeteria are: (1) I require the students to fall in line in the cafeteria (WAM= 2.80, Sometimes), (2) I enforce the students of the First Come, First Served in buying and paying their foods (WAM=2.09, Sometimes) and I warn the students to refrain from making a noise (WAM= 3.03 , Sometimes).

\section{Attendance at Mass}

The strategies employed by the respondents in overcoming the challenges they encountered in terms of attendance at mass by checking the mass card in the schedule day of submission (WAM= 3.30, Always).

\section{During the Flag Ceremony}

The strategies employed by the respondents in overcoming the challenges they encountered during the flag ceremony by giving a warning to the students who play or engage in any sport activities before the flag ceremony (WAM=3.53, Always).

\section{Use of School Facilities}

The strategies employed by the respondents in overcoming the challenges they encountered in terms of use of school facilities by reprimanding the students who commit vandalism (WAM= 3.43, Always). 


\section{School's Sustainable Waste Management Program}

The strategies employed by the respondents in overcoming the challenges they encountered in terms of school's sustainable waste management program is confiscate the ID of students who do not dispose of trashes properly (WAM=2.60, Sometimes).

\section{Off-campus School Activity}

The strategies employed by the respondents in overcoming the challenges they encountered in terms of off-campus school activity is asking the security guard to check the Parent's Permit Form of the student upon entering the school (WAM=3.23, Sometimes).

\section{Use of Cellphone and Other Gadgets}

The strategies employed by the respondents in overcoming the challenges they encountered in terms of use of cellphone and other gadgets by monitoring the cellphone or any gadget of the students to assure that they follow the rules and regulation implemented by the school (WAM= 3.53, Always).

\section{Boy-girl Relationship}

The strategies employed by the respondents in overcoming the challenges they encountered in terms of boy and girl relationship are: (1) conduct a conference with the students who show public display of affection or any immoral act (WAM=3.40, Always), (2) report to the guidance counselor or the prefect of discipline to address the violation of the students (WAM $=3.40$, Always), and (3) make an agreement to the students with the presence of proper authority, if they still continue his/her doing they will be suspended or expelled in the school (WAM=3.40, Always).

\section{Safety Measure}

The strategies employed by the respondents in overcoming the challenges they encountered in terms of safety measure by inspecting bags, wallets, and other personal belongings of students $(\mathrm{WAM}=2.47$, Seldom $)$.

\section{CONCLUSIONS}

Based on the findings of the study, the following conclusions were drawn:

1. This study revealed the challenges encountered by the Junior High School Teachers in terms of Code of Conduct Related to Discipline and Code of Conduct Related to Decorum. Those challenges, if not prevented, might affect the learning environment resulting in a disciplinary problem involving students.

2. In the findings of the study, the orientation for the students is needed to enhance for students' awareness on the rules and regulations implemented in the school. Moreover, the consistent adherence to the rules and regulations is really important in order to discipline the students. The strategies may vary depending on the violations/offenses committed by the students in terms of code of conduct related to discipline and code of conduct related to decorum. Also, the researcher notice that the strategy employed by the respondents mostly in positive reinforcement than negative reinforcement. 
3. The teacher's guidebook contains tips on how to manage the behavior of the students more effectively. The research output includes the monitoring checklist on the orientation of school policies.

\section{RECOMMENDATIONS} following:

In the light of the findings and conclusions of the study, the researcher recommended the

\section{For the Students}

1. They must fully understand the importance of the school's rules and regulations by seriously considering the school polices on code of conduct that were identified in this study.

\section{For the Teachers}

1. Conduct an annual orientation/re-orientation program that emphasizes the findings particularly on the research locale of this research.

2. Seriously consider more effective strategies to overcome problems on code of conduct.

3. Use the output of this study.

\section{For the School Administrators}

1. Issue a school memorandum requiring all teachers and school staff to strictly implement the school policies.

\section{For the Future Researchers}

1. Conduct a study on the assessment of the quality of school policies implemented in private schools in Quezon Province.

2. Another study on the same topic should be conducted but should utilize a wider scope and conduct a comparative analysis of the different strategies used by the teacher.

3. Teacher's Guidebook may be enhanced depending on the results and findings of another similar study.

\section{References}

Al-Amarat, M. S. (2011). The classroom problems faced teachers at the public schools in tafila province, and proposed solutions. Faculty of Education, Tafila Technical University, Tafila, Jordan, 3(1), 37-48. Retrieved October 31, 2018 from http://krepublishers.com/02Journals/IJES/IJES-03-0-000-11-Web/IJES-03-1-000-11-Abst-PDF/IJES-3-1-037-11041-Al-Amarat-M-S/IJES-3-1-037-11-041-Al-Amarat-M-S-Tt.pdf

Alejandra, M., \& Castaño, G. (2015). Classroom strategies that impact disruptive behavior on primary students. Retrieved October 30, 2018 from http://repositorio.utp.edu.co/dspace/bitstream/handle/11059/5522/371393G216.pdf?seque nce $=1$ 
Aranilla, E. C., \& Trinidad, E. J. (2014). Conformance with the policy of wearing ids by the students of the higher education department of sacred heart college. (Unpublished master's thesis). Sacred Heart College, Lucena City

Bafanz, R., \& Byrnes, B. (2012). The importance of being in school: a report on absenteeism in the nation's public schools. Retrieved October 25, 2018 from http://www.attendanceworks.org/wordpress

Bartle. (2015). Cellphone Should Banned in Schools. Retrieved April 2, 2019 from https://www.bartleby.com/essay/Cell-Phones-Should-Be-Banned-in-SchoolsFKCWAMUSVJ

Breaux, A., \& Whitaker, T. (2013). Three ways to better behavior . Virginia Journal of Education. Retrieved April 23, 2019 from http://www.veanea.org/home/1949.htm

Briones (2016). Interview. Retrieved April 24, 2019 from www. deped.gov.ph

Brunk, S. (2018). 5 ways to teach and encourage respect. Retrieved April 2, 2019 from https://www.steppingstoneschool.com/9971-2/

Cluj-Napoca. (2011). Educational strategies for improving student's behavior. Retrieved October 7, 2018 from https://doctorat.ubbcluj.ro/sustinerea_publica/rezumate/2011/stiinte-aleeducatiei/Andreason_Ecaterina_En.pdf

de Guzman et.al. (2008). From teaching from the heart to teaching with a heart: segmenting filipino college students' views of their teachers' caring behavior and their orientations as cared-for individuals. Asia Pacific Education Review, 9(4), 487-502. Retrieved April 17, 2018 from https://files.eric.ed.gov/fulltext/EJ835215.pdf

DepEd Order no. 1, s. 2003. Promulgating the implementing rules and regulations of republic act no. 9155. Retrieved April 24, 2019 from http://www.deped.gov.ph/2003/01/06/do1-s-2003-promulgating-the-implementing-rules-and-regulations-irr-of-republic-actno-9155-otherwise-known-as-the-governance-of-basic-education-act-of-2001/

DepEd Order no. 44, s. 2005. Declaration of school as zone of peace. Retrieved April 24, 2019 from http://www.deped.gov.ph/2005/08/08/do-44-s-2005-declaration-of- schools-aszones-of-peace/

DepEd Order no. 92, s. 1992. Revised manual of regulations of private schools (8th edition) amended by do 88, s. 2010 - 2010 revised manual of regulations for private schools in basic education do 35, s. 1993 - allowing student absences in excess of 20 per cent in individual cases in private schools. Retrieved April 24, 2019 from http://www.deped.gov.ph/1992/08/10/do-92-s-1992-1992-revised-manual-of-regulationsof-private-schools-8th-edition-amended-by-do-88-s-2010-2010-revised-manual-ofregulations-for-private-schools-in-basic-education-do-35-s-199/

Edrad, R. M. (2012). Classroom management difficulties encountered and coping strategies employed by public elementary school teachers of pagbilao district. (Unpublished master's thesis). Sacred Heart College, Lucena City 
Enverga, A. C., \& Tenorio, M. G. (2009). Campus security management: a factor in providing school campuses an atmosphere conducive to effective teaching and learning. MSEUF Research Studies V.11, XI(1).

ESL Teacher Board Classroom Management. (2008). Management of student behavior. Retrieved February 3, 2019 from http://www.adprima.com/managing.htm

Ferlazzo, L. (2018). Response: the best ways to resolve conflicts between students. Classroom Q \& A. Retrieved March 17, 2019 from https://blogs.edweek.org/teachers/classroom_qa_with_larry_ferlazzo/2018/02/response_t he_best_ways_to_resolve_conflicts_between_students.html

Flores, H. (2013). Private Schools Urged to have Anti-Bullying. Philippine Star, 8.

Garcia, A. G. (2009). DepEd clarifies ban on cellphones in the classroom. Manila Bulletin, p. 2.

Groep, J. (2019). Major classroom management. Retrieved April 2, 2019 from https://classroom.synonym.com/major-classroom-management-theories-6573859.html

Guido, M. (2018). 20 Classroom management strategies and techniques. Retrieved April 2, 2019 from https://www.prodigygame.com/blog/classroom-management-strategies/

Gusto, V. M. (2013). Evaluation of student services programs of higher education department of sacred heart college, lucena city: basis for three year development plan. (Unpublished master's thesis). Sacred Heart College, Lucena City

Herr, E. L. (2018). Guidance. In World Book Advanced. Retrieved April 23, 2019 from https://www.worldbookonline.com/advanced/article?id=ar239160

Huston University Online. (2019). Understanding three classroom management theories. Retrieved April 2, 2019 from https://online.husson.edu/classroom-management-theories/

Kalin, J., Peklaj, C., Pečjak, S., Levpušček, M. P., \& Zuljan, M. V. (2017). Elementary and secondary school students' perceptions of teachers' classroom management competencies. CEPS Journal: Center for Educational Policy Studies Journal, 7(4), 37-62. Retrieved April 23, 2019 from https://search.proquest.com/docview/1988416502?accountid=146485

Korinek, L. (2008). The positive classroom: a lunchroom solution. ASCD, 66, p. 1.

Kwayu, A. I. (2014). Perceptions of secondary students on school rules and regulations in promoting acceptable behavior: A Case of Moshi Rural District. Retrieved October 31, 2018 from http://repository.out.ac.tz/777/1/ADILISTER_ISHIKAELI_KWAYU.pdf

Langberg, J., \& Ciolfi, A. (2016). Busting the school-to-prison pipeline. Education Digest, 4447.

Linsin, M. (2015, October 15). Six classroom management tips for new teachers. The Guardian. Retrieved April 2, 2019 from https://www.theguardian.com/teachernetwork/2015/oct/08/classroom-management-tips-new-teachers

Logsdon. (2009). Increased desired behaviors with positive reinforcement national association for the education of young children, developmentally appropriate practices in early 
childhood classes serving children birth through age 8. Child Development Education Center. Retrieved April 23, 2019 from

https://www.msjc.edu/ChildDevelopmentEducationCenter/Documents/Child_Developme nt_and_Education_Centers/developmentally_appropriate_practice.pdf

Maria, S. N. (2013). Effectiveness of school rules and regulations in enhancing discipline in public secondary schools in kangundo division, machakos country, kenya. Retrieved October 25, 2018, from http://ir.cuea.edu/jspui/bitstream/1/90/1/Anna\%20Maria\%20Ndeto.pdf

Mateo, J. (2019). Off-campus activities of up education -exec. Philippine Star, p. 12.

Maxwell, L. (2017). Quiet riot: managing volume levels in a library. Retrieved April 2, 2019 from https://bookriot.com/2017/07/09/quiet-riot-managing-volume-levels-school-library/

Mcleod, S. (2018). Skinner-operant conditioning. Retrieved April 2, 2019 from https://www.simplypsychology.org/operant-conditioning.html

Meador, D. (2019). Simple rules all teachers should live by. ThoughCo. Retrieved April 2, 2019 from https://www.thoughtco.com/rules-teachers-should-follow-4120807

Memorandum Order No. 93 series of 2011. Mandated programs, projects and activities, various forms, and targets pertinent to the youth for environment in schools (yes) program. Retrieved April 24, 2019 from www. deped.gov.ph

Money, J. N. (2015). Pilot study: student behavior in inner-city schools: the impact. Retrieved October 7, 2018 from https://www.cn.edu/libraries/tiny_mce/tiny_mce/plugins/filemanager/files/Dissertations/J acqueline_Money.pdf

Mtsweni, J. (2008). The role of educators in the management of school discipline in the nkangala region of mpumalanga. University of South Africa. Retrieved April 2, 2013 from http://citeseerx.ist.psu.edu/viewdoc/download?doi=10.1.1.511.7455\&rep=rep1\&type=pdf

Nalandas Schools. (2014). The importance of guidance \& counselling a student's life. Retrieved April 2, 2019 from https://www.nalandaschool.org/importance-of-guidance-andcounselling

NEU. (2016). Health and safety. Retrieved April 2, 2019 from https://www.atl.org.uk/adviceand-resources/health-and-safety/parental-consent

Nooruddin, S., \& Baig, S. (2014). Student behavior management: school leader's role in the eyes of the teachers and students. International Journal of Whole Schooling, 10(2), 1-20. Retrieved October 7, 2018 from https://ecommons.aku.edu/cgi/viewcontent.cgi?article=1045\&context=pakistan_ied_pden

Orca. (2016). 9 ways to reduce garbage in the classroom. Retrieved April 2, 2019, from http://blog.orcabook.com/9-ways-to-reduce-garbage-in-the-classroom/

Organista, A. (2013). How to conduct effective consultation sessions with students?. Educator, pp. $46-47$. 
Panganiban, T. P. (2018). DepEd's briones opposes random checks on bags, lockers of students. Retrieved April 2, 2018, from https://www.gmanetwork.com/news/news/nation/655931/deped-rsquo-s-briones-opposesrandom-checks-on-bags-lockers-of-students/story/

Project Ideal (2013). Managing student behavior. Retrieved April 24, 2019, from http://www.projectidealonline.org/v/managing-student-behavior/

Pyror, B. (2013). Home visit boost attendance of the attendance of the students: evaluating student attendance. Retrieved October 25, 2018, from http://www.tattatendance.org/teaching-features-home-work-success/

Raftery, R. L. (2008). A quantitative study of the effectiveness of positive behavior support in secondary schools. Retrieved April 23, 2019 from https://scholarsarchive.byu.edu/etd/1623

Republic Act 9003. Ecological Solid Waste Management Act of 2000. Retrieved April 24, 2019 from www. deped.gov.ph

Republic Act No. 10627 (2013). An act requiring all elementary and secondary schools to adopt policies to prevent and address the acts of bullying in their institutions. Retrieved April 24, 2019 from https://www.officialgazette.gov.ph/2013/09/12/republic-act-no-10627/

Room 241 (2013). Tips for building characters in schools and students. Retrieved April 2, 2013 from https://education.cu-portland.edu/blog/classroom-resources/7-tips-for-buildingcharacter-in-schools-and-students/

Russo, N. L. (2014). The Impact of Adapting Classroom Management on an Elementary Teacher's Perception of Student Behavior. Retrieved October 7, 2018, from https://digitalcommons.brockport.edu/cgi/viewcontent.cgi?article=1447\&context=ehd_th eses

Republic Act no. 8491. Flag and Heraldic Code of the Philippines. Retrieved April 24, 2019 from www. deped.gov.ph

Shore, K. (2019). Dealing with School Vandalism. Retrieved April 2, 2019 from http://drkennethshore.nprinc.com/for-teachers/dealing-school-vandalism/

Sibal, M. R. (2013). Parent-Teacher Conferences. Educator, pp. 46

Simuforosa, M. A. (2014). Learner indiscipline in schools. Review of Arts and Humanities, 3(2), 79-88. Retrieved October 30, 2018 from http://rahnet.com/journals/rah/Vol_3_No_2_June_2014/6.pdf

Sprick, J., Alabiso, J., \& Yore, K. (2015). Dramatically improving attendance. Educational Leadership, 50-54.

Sun, R. C., \& L., S. D. (2012). Student classroom misbehavior: an exploratory study based on teachers' perceptions. The Scientific World Journal. Retrieved April 23, 2019 from doi:http://dx.doi.org/10.1100/2012/208907 
Teach Thought. (2017 ). 21 Simple ideas to improve students motivation. Retrieved April 2, 2019 from https://www.teachthought.com/pedagogy/21-simple-ideas-to-improve-studentmotivatio/

Usher, A., \& Kober, N. (2013). Student motivation an overlooked piece of school reform. The Education Digest.

Vega, R. D. (2018). Library. In World Book Advanced. Retrieved April 23, 2019 from https://www.worldbookonline.com/advanced/article?id=ar322340

Villarubia, R. C. (2017). A Closer Look at Bullying in Schools. The Modern Teacher.

Weebly. (n.d.). Behavior Management. Retrieved April 2, 2019 from https://behaviourmanagementreport.weebly.com/key-theorists.html

Wells, R. H. (2018). Successful School Discipline: How to get Students to Follow the Rules. Retrieved April 2, 2019 from https://www.youthchg.com/successful-school-discipline/

Whisman, A. \& Hammer, P. C. (2014). The association between school discipline and mathematics performance: A case for positive discipline approaches. Charleston, WV: West Virginia Department of Education, Division of Teaching and Learning, Office of Research. Retrieved from April 23, 2019 from www. Proquest.com 